\title{
The Importance of Comprehensive Care Among Obese Patients with Adult Spinal Degenerative Conditions
}

\author{
Cucnhat P Walker* \\ College of Pharmacy, Larkin University, USA
}

Submission: November 27, 2020; Published: December 09, 2020

*Corresponding author: Cucnhat P Walker, PharmD, MPH, BCPS, College of Pharmacy, Larkin University, Miami, USA

Keywords: Obesity; Spinal surgery; Adult spinal degenerative; Obese; Nutritional counseling

Abbreviations: BMI: Body Mass Index; ASD: Adult Spinal Deformities; DASH: Dietary Approaches to Stop Hypertension

\section{Opinion}

The Centers for Disease Control and Prevention has released the 2019 Adult Obesity Prevalence Maps. The maps show all states and territories had more than $20 \%$ of adults with obesity with 12 states having more than $35 \%$ obese adults. Only Colorado and the District of Columbia have $20 \%$ to $25 \%$ obese adults [1]. Obesity has been proven to be a significant risk factor for spinal degenerative conditions, for peri-operative and post-operative complications from spinal surgeries (i.e., longer operative times and increased blood loss, peri-operative peripheral nerve injury, post-operative infections, lower rate of spinal fusion, venous thromboembolism) [2-8]. In addition, the effects of obesity on post-operative clinical outcomes are controversial. Several studies, comparing obese and non-obese patients, showed no significant difference in outcome measures at a number of years after spinal surgeries while others demonstrated less improvement among obese patients and higher level of dissatisfaction with the surgical results [9-12]. Caution needs to be taken when interpreting these findings as obese patients tend to have worse pre-operative functional capacity than their counterparts.

Sturm R etal. study showed an almost linear increase in obesity rate at different levels from 2000 to 2010 and a 70\% increase from baseline in body mass index (BMI) greater than $40 \mathrm{~kg} / \mathrm{m}^{2}$ [13]. With this obesity epidemic, spinal surgeons perform an increasing number of spinal surgeries among this patient population over the years.

There is a great research gap in comprehensive medical care prior to the election of spinal surgeries among morbidly obese patients with adult spinal deformities (ASD). Their care starts with their primary care physicians who then refer them to pain management specialists and/or neurologists. After all pain treatment modalities have been exhausted and the patients still have moderate and severe pain, they are then referred to spinal surgeons for surgical evaluations. ASDs are multi-faceted diseases, which are complicated much further by morbid obesity. The medical care provided by the primary care physicians is quite complex and involves treatments by other specialties such as physical therapists, nutritionist or dietitians, and psychologists. The pain disorder secondary to adult spinal deformities is a complex medical condition that can be both pathologic and psychogenic, especially among obese patients. These patients may also have additional psychological issues which lead to their eating disorders and significant weight gain to begin with.

According to Dr. Michael Gordon, an orthopedic surgeon who is also specialized in neck and spine surgeries, almost $90 \%$ of his patients with BMIs greater than $35 \mathrm{~kg} / \mathrm{m}^{2}$ have never seen a nutritionist or dietitian [14]. While research evidence on interdisciplinary care involving primary care physicians and nutritionists/dietitians in the outpatient setting in the United States is limited to none, a Canadian survey-based study on 451 Canadian-trained family physicians practicing in British Columbia showed that the barriers to nutrition counseling perceived by these physicians were time and compensation being the strongest barrier, followed by inadequate training in medical school and post-graduate training [15]. Another Lebanese survey-based study among patients with type 2 diabetes mellitus revealed suboptimal 
use of dietary counseling services by these patients due to the lack of physician's referral, financial support for outpatient care, and patient's belief in the usefulness of dietary counseling [16].

From my personal interviews with my colleague family physicians, neurologists and pain management specialists, nutritional counseling in their clinics go as far as a five to ten minute talk to patients about Dietary Approaches to Stop Hypertension (DASH) or Mediterranean diet and their recommendation to the patients to lose weight without further guidance or referral. Based on these interviews and a literature search for research evidence in this area, this indicates the need to increase referral to nutritionists and dietitians among obese patients with ASD [17]. Another important element that has been lacking and overlooked in the care of these patients is psychological evaluation and therapy throughout their care, not just a one-time routine presurgical psychological evaluation. Depression is well described among obese patients [18-21]. A mere five-minute counseling on weight loss to these patients is nothing but dropping a grain of salt in three gallons of water to make it salty.

Treatment of ASD among morbid obesity is complex and requires significant interdisciplinary collaborations with many other specialties. Many aspects of care for these patients have been overlooked while there is a significant gap in research in this area. Before the decision for spinal surgeries is made, conservative treatment needs to be reviewed to identify missing gaps such as nutritional counseling with nutritionists and dietitians and psychological evaluation and treatment to help improve patient care outcomes.

\section{References}

1. (2019) Adult Obesity Prevalence Maps. Overweight \& Obesity. The Centers for Disease Control and Prevention.

2. Kieser DC, Wyatt MC, Boissiere L, Kazunori H, Derek TC, et al. (2019) The effect of increasing body mass index on the pain and function of patients with adult spinal deformity. J Spine Surg 5(4): 535-540.

3. El-Kadi M, Donovan E, Kerr L, Coby C, Victor O, et al. (2019) Risk factors for postoperative spinal infection: A retrospective analysis of 5065 cases. Surg Neurol Int 10(121).

4. Shiri R, Solovieva S, Husgafvel-PK, Risto T, Xiaolin Y, et al. (2013) The role of obesity and physical activity in non-specific and radiating low back pain: the Young Finns study. Semin Arthritis Rheum 42(6): 640650.

5. Shiri R, Karppinen J, Leino-AP, Svetlana S, EV-Juntura (2010) The association between obesity and low back pain: a meta-analysis. Am J Epidemiol 171(2): 135-154.

6. Teraguchi M, Yoshimura N, Hashizume H, S Muraki, H Yamada, et al.
(2014) Prevalence and distribution of intervertebral disc degeneration over the entire spine in a population-based cohort: the Wakayama Spine Study. Osteoarthritis Cartilage 22(1): 104-110.

7. Samartzis D, Karppinen J, Cheung JP, Jeffrey Lotz (2013) Disk degeneration and low back pain: are they fat-related condition? Global Spine J 3(3): 133-144.

8. Samartzis D, Karppinen J, Mok F, Daniel YTF, Keith DKL, et al. (2011) A population-based study of juvenile disc degeneration and its association with overweight and obesity, low back pain, and diminished functional status. J Bone Joint Surg Am 93(7): 662-670.

9. Rihn JA, Radcliff K, Hilibrand AS, David TA, Wenyan Z, et al. (2012) Does obesity affect outcomes of treatment for lumbar stenosis and degenerative spondylolisthesis? Analysis of the Spine Patient Outcomes Research Trial (SPORT). Spine (Phila Pa 1976) 37(23): 1933-1946.

10. Djurasovic M, Bratcher KR, Glassman SD, John RD, Leah YC (2008) The effect of obesity on clinical outcomes after lumbar fusion. Spine (Phila Pa 1976) 33(16): 1789-1792.

11. Knutsson B, Mechaelsson K, Sanden B (2013) Obesity is associated with inferior results after surgery for lumbar spinal stenosis: a study of 2633 patients from the Swedish spine register. Spine (Phila Pa 1976) 38(5) :435-441.

12. Rihn JA, Kurd M, Hilibrand AS, Jon L, Wenyan Z, et al. (2013) The influence of obesity on the outcome of treatment of lumbar disc herniation: analysis of the Spine Patient Outcome Research Trial (SPORT). J Bone Joint Surg Am 95(1): 1-8.

13. Sturm R, Hattori A (2013) Morbid obesity rates continue to rise rapidly in the United States. Int J Obes (Lond) 37(6): 889-891.

14. Gordon M (2016) Why your orthopedic surgeon is not fat-shaming you. It's not about fat shame - It's about fat facts. Newport Orthopedic Institute.

15. Wynn K, Trudeau JD, Taunton K, Margot G, Ian Scott (2010) Nutrition in primary care: current practices, attitudes, and barriers. Can Fam Physician 56(3): e109-e116.

16. Alameddine M, Nasreddine L, Hwalla N, Yara M, Hikma S, et al. (2013) Factors associated with consulting a dietitian for diabetes management: a cross-sectional study. BMC Health Serv Res 13: 504

17. Luig T, Keenan L, Campbell-SDL (2019) Transforming health experience and action through shifting the narrative on obesity in primary care encounters. Qual Health Res 30(5): 730-744.

18. Ogden J, Clementi C (2010) The experience of being obese and the many consequences of stigma. Journal of Obesity.

19. Simon GE, Ludman EJ, Linde JA, Belinda HO, Laura I, et al. (2008) Association between obesity and depression in middle-aged women. Gen Hosp Psychiatry 30(1): 32-39.

20. Carey M, Small H, Young SL, Allison B, Alessandra B, et al. (2014) Prevalence of comorbid depression and obesity in general practice: a cross-sectional survey. Br J Gen Pract 64(620): e122-e127.

21. Luppino FS, De Wit LM, Bouvy PF Theo S, Pim C, et al. (2010) Overweight, obesity, and depression: A systematic review and metaanalysis of longitudinal studies. Arch Gen Psychiatry 67(3): 220-229. 


\section{Your next submission with Juniper Publishers will reach you the below assets}

- Quality Editorial service

- Swift Peer Review

- Reprints availability

- E-prints Service

- Manuscript Podcast for convenient understanding

- Global attainment for your research

- Manuscript accessibility in different formats ( Pdf, E-pub, Full Text, Audio)

- Unceasing customer service

Track the below URL for one-step submission https://juniperpublishers.com/online-submission.php 